\title{
Vanhuspalveluhankkeet vetovoimaisuuden vahvistajina
}

\author{
Merja Harmoinen ja Niina Kaukonen
}

\section{Vanhuspalvelujen vetovoimaisuus huolena}

Vanhusten hoitotyön vetovoimaisuudesta on herännyt aiheellinen huoli, sillä työpaineista kärsivää vanhustyötä rasittavat suuret muutokset. Työvoimapula koettelee tulevaisuudessa eniten kuntasektoria, josta 32 prosenttia lähihoitajista ja 25 prosenttia sairaanhoitajista eläköityy vuoteen 2028 mennessä (Keva 2020). Osaavan henkilökunnan saamisen eläköityvien tilalle ennustetaan vaikeutuvan. Tarve hoitohenkilökunnan rekrytointiin lähitulevaisuudessa kasvaa suuresti vanhusten ympärivuorokautisen hoivan yksiköiden vähimmäishoitajamitoituksen kasvaessa 0,7 hoitajaan hoidettavaa kohti. (Valtioneuvosto 2019.)

Hoitajavajetta korvaavia hoitotyön koulutuspaikkoja on lisätty jo vuonna 2020 tarvetta vastaavaksi, ja määriä lisätään myös lähitulevaisuudessa (Opetus- ja kulttuuriministeriö 2019). Pulma ei kuitenkaan ole koulutuspaikkojen määrässä vaan siinä, että hoitotyön ammatit ovat huolestuttavasti menettäneet vetovoimaansa eikä hakijoita ole nykyisiinkään koulutuspaikkoihin riittävästi (Vipunen 2020).

Vähenevien hakijoiden ja jo opiskeluvaiheessa lähtöä suunnittelevien opiskelijoiden lisäksi hoitoalaa kuormittaa hoitajien alalta pako. Hoitajiksi valmistuvien märä ei sinänsä ole laskenut, mutta sairaanhoitajaopiskelijoista joka neljäs aikoo vaihtaa alaa valmistuttuaan (Sairaanhoitajaliitto 2019). Kansainvälisissä (ks. esim. Burmeister ym. 2019; Camveren ym. 2020) ja kotimaisissa (ks. Helander ym. 2019;
Slater ym. 2021) tutkimuksissa on todettu, että etenkin nuorilla sairaanhoitajilla on odotettua suurempi halu lähteä työstä ja ammatista. Kansainvälisen hoitajien työstä lähtemisaikeita ja työstä poissaoloa koskevien tutkimusten mukaan sekä työstä lähtemisaikeita että poissaoloja lisäsivät työpaikan hoitohenkilökunnan riittämättömyys, alhainen työtyytyväisyys, vähäinen työkokemus hoitajana ja nuori ikä (Burmeister ym. 2019) sekä ammatillisen solidaarisuuden ja johtajien tuen puute sekä työn ja yksityiselämän yhteensopimattomuus (Camveren ym. 2020). Suomalaisten nuorten sairaanhoitajien ammatista luopumisaikeiden syinä olivat tutkimuksen mukaan palkkatyytymättömyys, kohtuuttomat työn vaatimukset, puutteellinen perusta omalle työlle hoitoalalla, oman jaksamattomuuden uhka sekä huonot työskentelyolosuhteet (Helander ym. 2019).

Nuorten sairaanhoitajien ammatista luopumisaikeiden syitä on havaittavissa myös pohjoismaisessa kotihoidon ja laitoshoidon vanhustyötä vuosina 2005 ja 2015 vertailevassa NORDCARE2-tutkimushankkeessa. Kotihoidon asiakasmäärät olivat nousseet jokaisessa työvuorossa merkittävästi ja olivat Suomessa muita Pohjoismaita korkeammat. Työntekijöillä oli riittämättömyyden tunteita, koska he eivät kokeneet pystyvänsä tarjoamaan asiakkailleen riittävää hoitoa. Nykyisen työnsä lopettamista vakavasti harkitsevien osuus oli kaksinkertaistunut Suomessa kymmenessä vuodessa, ja vuonna 2015 jopa kaksi viidestä kotihoidon työntekijästä harkitsi lopettamista. Laitoshoidon puolella kymmenen vuoden ai- 
kana tapahtuneet muutokset olivat vähäisempiä, mutta lähtötilanne oli kotihoitoa heikompi, henkilöstömäärä pienempi ja työ raskaampaa. Huomattava muutos oli laitoshoidon työntekijöiden kasvanut huoli omasta terveydestään ja turvallisuudestaan. Laitoshoidon henkilökunta arvioi työolosuhteidensa heikentyneen, ja työnsä lopettamista harkitsi lähes kaksi viidestä. Hoitajien näkemys työn saamasta arvostuksesta oli heikolla tasolla sekä vuonna 2005 että 2015. (Kröger ym. 2018.)

Vanhusten hoitotyön arvostukseen liittyviä tekijöitä tuli esille myös tutkimuksessa, joka koski hoivatyöntekijöiden työn kuormittavuutta ja teknologian käyttöä vanhustyössä sekä työn kannustavia tekijöitä (Rytkönen 2018). Enemmistö hoitajista arvioi, etteivät kunnan virkamiehet ja poliitikot arvosta heidän työtään tai arvostavat sitä vain vähän. Myös vanhustyön yleistä arvostusta pidettiin vähäisenä. Hoitajat itse arvostivat omaa työtään ja saivat arvostusta myös asiakkailta ja työtovereilta. Kannustavia ja voimavaroja lisääviä tekijöitä olivat asiakkaat, halu auttaa ihmisiä, oman ammatin saaminen ja monipuoliset työtehtävät. Monille työntekijöille merkityksellisiä olivat työn sisältö, työyhteisö ja turvattu toimeentulo.

Tämän kirjoituksen tavoitteena on pohtia Etelä-Savon sairaanhoitopiirin vanhuspalveluhankkeita vetovoimaisuuden näkökulmasta ja tuoda esille vanhustyön myönteisiä puolia.

\section{Hankkeet vetovoimaisuuden edistäjinä}

Etelä-Savon sosiaali- ja hyvinvointipalveluissa (myöhemmin Essote) on käynnissä useita joko Essoten hallinnoimia vetovoimaisuuteen liittyviä vanhustyötä kehittäviä hankkeita tai toisten tahojen hallinnoimia hankkeita.

\section{Vetovoimainen kotihoito}

Vetovoimainen kotihoito -hankkeen työpajoissa pyrittiin kehittämään Mitä kuuluu -työ- hyvinvointikyselyssä (TTL 2020) havaittuja epäkohtia. Kyselyn tulosten mukaan työntekijät kokivat vaativina työn jatkuvat keskeytykset, runsaan määrän muistettavia asioita sekä sen, että heillä ei ollut mahdollisuutta vaikuttaa työaikoihinsa. Eettinen kuorma tuntui ajoittain raskaalta, ja myös lähijohtajaa kaivattiin enemmän hoitotyöhön. Myönteistä vastaajien mukaan oli, että kotihoidon työntekijät kokivat työn imua ja panostivat työhönsä. Työyhteisöissä oli sosiaalista vahvuutta sekä "me-henkeä", ja lähijohtajia pidettiin oikeudenmukaisina, kannustavina ja itsenäistä työtä tukevina.

Työpajoissa kehitettiin ja käytännössä kokeiltiin esimerkiksi yhteisöllistä työvuorosuunnittelua, suunniteltiin toimintatapa työtä keskeyttävien puheluiden keskittämiseksi sekä selkeytettiin työprosesseja kirkastamalla yhteisiä pelisääntöjä, rooleja ja vastuita työssä. Perehdytysmateriaalia päivitettiin vastaamaan paremmin työntekijöiden odotuksia ja kokeilemalla perehdyttämistä pelillistämisen avulla. Muistityön avuksi laadittiin check-listat. Myönteistä some-näkyvyyttä lisättiin. (Kotikulma 2021.)

\section{Teknologia avuksi}

Hoitotyön fyysistä raskautta pyrittiin keventämään teknologian avulla. Kotona asumisen teknologiat ikäihmisille -ohjelmassa (KATI) uusia teknologisia ratkaisuja kehitettiin yhdessä asiakkaan kanssa, jotta ne tulivat luontevaksi osaksi asiakkaan kotielämää. Hoitaja osasi hyödyntää kehitettyjä ratkaisuja ja helpottaa asiakkaan elämää ja omaa työtään. (THL 2020.) Teknologisista kotiratkaisuista hyötyvät esimerkiksi Haukivuoren taajamassa asuvat ikäihmiset (Essote 2020), joista Ennakoimalla elinikäistä toimintakykyä -hankkeen (Ikä SIB) tavoitteen mukaisesti suurimman osan (94\%) on mahdollista asua kotona yli 75-vuotiaiksi. (Essote 2021.) 


\section{Hyvä veto}

Hoitotyön eettistä kuormaa helpotetaan edelleen käynnissä olevassa Hyvä veto -hankkeessa, jossa henkilökunta ja heidän lähijohtajansa pohtivat työnsä eettisesti raskaita asioita ja etsivät keinoja niiden vähentämiseksi. Työmenetelminä ovat henkilöstön ja lähijohtajien haastattelut sekä työpajat. Lähijohtajia ohjataan käyttämään työssään valmentavaa johtamista. Vastatulleiden työntekijöiden työn aloittamista tuetaan mentoreiden avulla siten, että uusi työntekijä saa työparikseen kokeneen henkilön, jonka kanssa työhön perehdytään suunnitelmallisesti. Työyhteisön tietoa eettisestä organisaatiokulttuurista, valmentavasta johtamisesta sekä eri-ikäisten työntekijöiden yhteistyön mahdollisuuksista edistää vanhuspalveluita välitetään myös yhteiskunnallisille päättäjille. (TTL 2021.)

\section{Strateginen työkykyjohtaminen}

Työkykyyn paneuduttiin Strateginen työkykyjohtaminen (2019-2021) -hankkeessa (TTL 2019), jossa sote-organisaatiot uudistivat jo olemassa olevia työkykyjohtamisen mallejaan ja hyviä käytäntöjään siten, että ne vastaisivat paremmin toimintaa uudessa ja muuttuvassa sosiaali- ja terveydenhuollossa. Hankkeen aikana saatiin tietoa organisaation muutosvaiheesta, siitä millaisia työkyvyn hallinnan malleja ja prosesseja oli käytössä ja etenkin siitä, minkälaista tukea niiden kehittämiseen tarvittiin. Essotessa rakennettiin hankkeen tuloksena työkykytalo, jossa oli kuvattu työntekijöiden, lähijohtajien ja ylimmän johdon näkemykset omasta osuudestaan työkykyisyyteen. Työntekijät, lähijohtajat ja ylin johto kuvattiin samantasoisesti, ei hierarkkisesti.

\section{Terveenä eläkkeellä}

Ikääntyvien työntekijöiden parempaa terveyttä tavoiteltiin puolestaan Terveenä eläkkeellä -hankkeessa (XAMK 2021). Riskialttiiden henkilöiden tunnistaminen, heidän työkykynsä vahvistaminen viimeisinä työvuosina ja eläkkeelle siirtymisen tuomiin muutoksiin valmistautuminen havaittiin merkitykselliseksi. Valmistautuminen tarkoitti esimerkiksi ravitsemuksen, liikunnan, unen ja sosiaalisen elämän kohentamista päivittäisen hyvinvoinnin edistämiseksi. (XAMK 2021.) Apuna eläkkeelle valmistautumiseen oli yhteiskunnallinen markkinointi, jolla pyrittiin käyttäytymisen myönteiseen muutokseen. Ajatuksena yhteiskunnallisessa markkinoinnissa on tarjota ihmisille sitä, mitä he haluavat, mistä he pitävät ja mikä on helposti saavutettavissa. (Soste 2021.)

\section{Pohdinta}

Tässä kirjoituksessa pohdittiin Etelä-Savon sairaanhoitopiirin vanhuspalveluhankkeita vetovoimaisuuden näkökulmasta. Hankkeiden tuoma tieto kertoo vanhuspalveluiden henkilöstöä koskevia sekä myönteisiä että kehitettäviä asioita.

Vetovoimainen kotihoito -hankkeen myötä työntekijöiden osallisuus oman työnsä aktiivisina toimijoina lisääntyi ja heidän näkemystensä arvostaminen oman työnsä kehittäjinä tuli näkyväksi (Kotikulma 2021). Hyvä veto -hankkeessa puolestaan hoitajat ja lähijohtajat kertoivat arvokkaita näkemyksiä oman ja työyhteisön eettisen hyvinvoinnin kehittämiseen, minkä lisäksi he saivat tietoa työyhteisön eettisestä kehittämisestä. Yhteinen työasioiden pohdinta lisäsi kollegiaalisuutta työryhmässä. Tutkimuksissa on havaittu samansuuntaisesti, että työntekijöiden ja lähijohtajien keskeisyys oman työnsä aktiivisina toimijoina sekä kollegiaalisuus ovat keskeisiä työhyvinvoinnin ja työhön jäämisen vahvistajia (Ahlstedt ym. 2019; Loft ym. 2020).

Myönteistä oli, että kotihoidon työntekijät kokivat työnimua ja pitivät johtamista hyvätasoisena (TTL 2020). Osa vastaajista toivoi lähijohtajan olevan enemmän mukana hoitotyössä. Tähän näkemykseen ovat saattaneet vaikuttaa 
koronatilanteen aiheuttamat rajoitukset, jotka estivät tiimipalaverit ja etäännyttivät lähijohtajaa tiimeistään. Lähijohtajien vähäinen läsnäolo saattaa viitata myös siihen, että heillä ei ollut riittävästi aikaa. Lähijohtajien työtä koskevassa tutkimuksessa (Sveinsdottir ym. 2017) havaittiin, että lähijohtajien aika kului työolojen kehittämisen sijaan muihin asioihin, kuten puhelimessa olemiseen, kokouksiin ja sähköposteihin vastaamiseen. Aikaa jäi vain minimaalisesti henkilöstön kehittämiseen, rohkaisemiseen ja voimaannuttamiseen tai näyttöön perustuvien käytäntöjen kehittämiseen, mikä kaikki on keskeistä nykypäivän terveydenhuollossa. (Sveinsdottir ym. 2017.) Etelä-Savon sairaanhoitopiirissä onkin lisätty vanhuspalveluihin lähijohtajia, jotta johdettavat alueet olisivat kohtuullisen kokoisia ja lähijohtajat mahdollisimman hyvin työntekijöiden tavoitettavissa (Kaukonen 2021).

Etelä-Savon sairaanhoitopiirin kotiin tarjottavien palveluiden työntekijöistä vain harvat olivat palkitsemiseen tyytyväisiä (TTL 2020). Tulos on samansuuntainen muiden hoitotyön tekijöiden palkkaa ja palkitsemista koskevien tutkimusten kanssa. Tyytymättömyys palkkaan ja palkitsemiseen onkin yleistä ja aiheellista hoitoalalla. Hoitotyön palkat ovat Suomessa Pohjoismaiden heikompia, mikä aiheuttaa alalta pakoa ja mahdollisesti muuttoa toisiin Pohjoismaihin. (Suomen virallinen tilasto 2017.) Myös Sairaanhoitajien työolobarometrissa (2020) havaittiin, että tyytymättömyys palkkauksen kannustavuuteen on jo hälyttävällä tasolla eikä palkkaus nouse työn vaativuuden mukaan (Sairaanhoitajaliitto 2021). Palkitseminen käsittää rahallisen palkan ja palkkioiden lisäksi aineettomat palkkiot. Palkitsemista koskevan väitöstutkimuksen mukaan aineettomista palkitsemistavoista arvostus, palaute työyhteisöltä, työajan järjestelyt, työn sisältö sekä mahdollisuus kehittyä, vaikuttaa ja osallistua olivat yhteydessä palkitsemisen merkitykseen. Kyseisten palkitsemistapojen korostuminen ei kuitenkaan tarkoita ai- neellisten palkkioiden väheksymistä sairaanhoitajien palkitsemisessa. (Seitovirta 2018.)

Mitä kuuluu -kyselyn mukaan kotiin tarjottavien palvelujen hoitohenkilökunta ei voinut riittävästi vaikuttaa työaikoihinsa (TTL 2020). Tämä tulos oli samansuuntainen laajan eurooppalaisen työaikoja koskevan tutkimuksen kanssa, jossa havaittiin, että yhä yleisimmiksi tulevat hoitajien 12 tunnin työvuorot lisäävät burnoutia ja emotionaalista väsymistä sekä heikentävät henkilökohtaisia työtuloksia ja vähentävät potilasturvallisuutta. Hoitajat, jotka työskentelivät 12 tunnin vuoroissa, olivat muita todennäköisemmin tyytymättömämpiä työhönsä ja työvuorojen joustamattomuuteen sekä taipuvaisempia lähtemään työstään. (Dall' Ora ym. 2015.)

Kotiin annettavien palvelujen vastaajat huomasivat työssään myönteisiä asioita, kuten johtaminen, sosiaalisesti vahva työyhteisö ja hyvät työolot, jotka tutkimusten mukaan edistävät työhön jäämistä. Tutkimusten mukaan jäämistä edistäviä asioita ovat arvostus, johtaminen ja työpaikan olosuhteiden kehittäminen hoitajia yksilöllisesti kohtelevaan suuntaan. Luottamuksen ja tuen, osallistumisen ja arvostuksen ilmapiiri saattaa vähentää työväsymystä ja edistää työhön jäämistä. (Bobbio \& Manganelli 2015.) Myös arvostavan johtamisen - jolla tarkoitetaan suunnitelmallista johtamista, tasa-arvoisuutta, osaamisen arvostamista ja työssä jaksamisen edistämistä - on havaittu lisäävän työhön sitoutumista ja työpaikkaan jäämistä (Harmoinen ym. 2015). Onnistuneiden asioiden on havaittu lisäävän työpaikan hyvää mainetta, ja ne mahdollistavat onnistuneen rekrytoinnin ja lisäävät hoitotyön henkilökunnan työhönsä jäämistä (Lasater ym. 2019). Magneettisairaaloissa eli vetovoimaisissa sairaaloissa on havaittu olevan vähemmän hierarkkinen sairaalarakenne, hoitajien osallistuvan päätöksentekoon ja autonomisuuden olevan suurempaa (Burmeister ym. 2019). Hoitajapula, työtyytymättömyys ja työstä lähteminen ovat matalammalla tasolla kuin ei-veto- 
voimaisissa sairaaloissa (Marquez-Hernandes ym. 2020).

Hankkeiden tuottamaa tietoa ja kokemusta hyödynnetään Etelä-Savon ikääntyneiden palvelukokonaisuuden valmistelussa, ja ne on otettu mukaan Etelä-Savon ikäohjelman tavoitteisiin pyrkimyksenä lisätä veto- ja pitovoimaa vanhuspalveluihin (Etelä-Savon hyvinvointialue 2020). Tässä kirjoituksessa esitettyjen hankkeiden toiminta ja niiden tuottama tieto virittää Etelä-Savon sairaanhoitopiirin työyksiköissä ajankohtaista keskustelua ja toimintaa

\section{Kirjallisuus}

Ahlstedt C, Eriksson Lindvall C, Holmström IK, Muntlin- Athlin Å. What makes registered nurses remain in work? An ethnographic study. Int J Nurs Stud 2019;89:32-8. https://doi.org/10.1016/j.ijnurstu.2018.09.008

Bobbio A, Manganelli AM. Antecedents of hospital nurses' intention to leave the organization: a cross sectional survey. Int J Nurs Stud 2015;52(7):1180-92. https://doi.org/10.1016/j.ijnurstu.2015.03.009

Burmeister EA, Kalisch BJ, Xie B, Doumit MAA, Eunjoo L, Ferraresion A, et al. Determinants of nurse absenteeism and intent to leave: an international study. J Nurs Manag 2019;27(1):143-53. https://doi.org/10.1111/jonm.12659

Çamveren H, Yürümezoğlu Arslan H, Kocaman G. 2020. Why do young nurses leave their organization? A qualitative descriptive study. Int Nurs Rev 2020;67(4):519-28. https://doi.org/10.1111/inr.12633

Dall'Ora C, Griffiths'P, Ball J, Simon'M, Aiken LH. Association of $12 \mathrm{~h}$ shifts and nurses' job satisfaction, burnout and intention to leave: findings from a cross-sectional study of 12 European countries. BMJ Open 2015;5(9):e008331. http://doi.org/10.1136/bmjopen-2015-008331

Essote. Ikä- ja muistiystävällinen Haukivuoren taajama. 2020. Internet: https://www.essote.fi/haukivuoresta-tulee-ika-ja-muistiystavallinen-taaja$\mathrm{ma} /$ (viitattu 12.9.2021).

Essote. Ikäystävällinen Etelä-Savo. 2021. Internet: https://etela-savo.fi/hyvinvointialueen-valmistelu/ikaohjelma (viitattu 12.9.2021). vetovoimaisuuden lisäämisestä. Kuuntelemalla ja ottamalla henkilökunta mukaan oman työn suunnitteluun ja toteutukseen ja positiiviseen viestimiseen omasta työstä voidaan lisätä osallisuutta ja työhyvinvointia sekä luoda aidosti yhteinen työpaikka.

\section{Yhteydenotto:}

\section{Merja Harmoinen, TtT}

lehtori, Kaakkois-Suomen ammattikorkeakoulu post doc- tutkija, Tampereen yliopisto merja.harmoinen@tuni.fi

Etelä-Savon hyvinvointialue. Miltä ikääntyneiden palvelut näyttävät vuonna 2030? 2020. Internet: https://etela-savo.fi/milta-ikaantyneiden-palvelut-nayttavat-vuonna-2030/ (viitattu 19.11.2021).

Harmoinen M, Niiranen V, Helminen M, Suominen T. Arvostavan johtamisen yhteys työhön sitoutumiseen ja ammatista lähtemiseen sekä urakehitykseen ja joustavuuteen työssä. Tutkiva hoitotyö 2015;13(2):4-13.

Helander M, Roos M, Suominen T. Nuorten sairaanhoitajien näkemyksiä ammatista lähtemisestä. Hoitotiede 2019;3(31):180-90. http://urn.fi/URN:NBN:fi:tuni-201911296452

Kaukonen, N. Kommenttipuheenvuoro Essoten vanhuspalveluiden vetovoimaisuudesta. 19.11.2021.

Keva. Kunta-alan ja valtion eläköitymisennuste 2020-2039: pohjautuen vakuutettuihin 31.12. 2018. 2020. Internet: https://www.keva.fi/globalassets/2-tiedostot/tama-on-keva--tiedostot/kunta-alan-ja-valtion-elakoitymisennuste-2020-2039.pdf (viitattu 12.9.2021).

Kotikulma. Työhyvinvointiin satsataan Essoten kotihoidossa. 2021. Internet: https://issuu.com/essote/docs/kotikulma_2021_1(viitattu 19.11.2021).

Kröger T, Van Aerschot L, Puthenparambil J. M. Hoivatyö muutoksessa: suomalainen vanhustyö pohjoismaisessa vertailussa. YFI- julkaisuja. Jyväskylän yliopisto, 2018. http://urn.fi/URN:ISBN:978-951-39-7372-8

Lasater KB, Richards RR, Dandapani NK, Burns LR, McHugh MD. Magnet hospital recognition in hospital systems over time. Health Care Man- 
age Rev 2019;44(1):19-29.

https://doi.org/10.1097/

\section{HMR.0000000000000167}

Loft MI, Jensen CS. What makes experienced nurses stay in their position? A qualitative interview study. J Nurs Manag 2020;28(6):1305-16. https://doi.org/10.1111/jonm.13082

Márquez-Hernández VV, Belmonte-García T, Gutiérrez-Puertas L, Granados-Gámez G. Original research: how magnet hospital status affects nurses, patients, and organizations: a systematic review. Am J Nurs. 2020;120(7):28-38.

https://doi.org/10.1097/01.

NAJ.0000681648.48249.16

Opetus- ja kulttuuriministeriö. Sairaanhoitajakoulutuksen aloituspaikkoja lisätään 180:1la ensi vuonna. 2019. Internet: https://minedu.fi/-/sairaanhoitajakoulutuksen-aloituspaikkoja-lisataan-180-1la-ensi-vuonna (viitattu 12.9.2021).

Rytkönen A. 2018. Hoivatyöntekijöiden kuormittavuus ja teknologian käyttö vanhustyössä. Acta Electronica Universitatis Tamperensis 1920. Tampere, 2018. https://urn.fi/URN:ISBN:978-952-03-0829-2

Sairaanhoitajaliitto. Kysely sairaanhoitajaopiskelijoille - tulokset. 2019. Internet: https://sairaanhoitajat.fi/wp-content/uploads/2020/02/Opiskelijakyselyn-tulokset_2019.pdf (viitattu 12.9.2021).

Sairaanhoitajaliitto. Sairaanhoitajien työolobarometri 2020. 2021. Internet:

https://sairaanhoitajat.fi/wp-content/uploads/2021/03/TYO\%CC\%88OLOBAROMETRI_2020_la\%CC\%88hdesivu_poistettu-netti-9.3.2021-uusiksi.pdf (viitattu 12.9.2021).

Seitovirta J. 2018. Sairaanhoitajien palkitseminen erikoissairaanhoidossa, perusterveydenhuollossa ja yksityisessä terveydenhuollossa. Publications of the Univeristy of Eastern Finland, Dissertations in Health Sciences. Kuopio, 2018. http://urn.fi/URN:ISBN:978-952-61-2944-0

Slater P, Roos M, Eskola S, McCormack B, Hahtela N, Kurjenluoma K, Suominen T. Challenging and redesigning a new model to explain intention to leave nursing. Scand J Caring Sci 2021;35(2):626-35. https://doi.org/10.1111/scs.12884

Soste. Yhteiskunnallinen markkinointi. 2021. Internet: https://www.soste.fi/jarjestoopas/yhteiskunnallinen-markkinointi/ (viitattu 12.9.2021).
Suomen virallinen tilasto. Palkkarakenne. Helsinki: Tilastokeskus, 2017. Internet: http://www.stat. fi/til/pra/2016/pra_2016_2017-09-21_tie_001_ fi.html?ad=notify (viitattu 12.9.2021).

Sveinsdottir H, Blondal K, Jonsdottir HH, Bragadottir H. 2017. The content of nurse unit managers' work: a descriptive study using daily activity diaries Scand J Caring Sci 2017;32(2):861-70. https://doi.org/10.1111/scs.12517

THL. Kotona asumisen teknologiat ikäihmisille -ohjelma (KATI). Terveyden ja hyvinvoinnin laitos, 2020. Internet: https://thl.fi/fi/tutkimus-ja-kehittaminen/tutkimukset-ja-hankkeet/kotona-asumisen-teknologiat-ikaihmisille-ohjelma-kati- (viitattu 12.9.2021).

TTL. Strateginen työkykyjohtaminen sote-muutoksessa. Työterveyslaitos, 2019. Internet: https://www.ttl.fi/tutkimushanke/strateginen-tyokykyjohtaminen-sote-muutoksessa-2019-2021/ (viitattu 12.9.2021).

TTL. Mitä kuuluu? -tulosportaali. Tulevaisuuden sote-keskus. Hankesuunnitelma Etelä-Savon maakunta 15.4.2020. Työterveyslaitos, 2020. Internet: https://www.ttl.fi/palvelu/mita-kuuluu-hyvinvointikysely-sote-alan-henkilostolle/ (viitattu 12.9.2021).

TTL. Henkilöstön saatavuuden ja alan vetovoimaisuuden turvaaminen iäkkäiden palveluissa. (Hyvä veto). Tutkimustiedote. Työterveyslaitos, 2021. Internet: https://www.ttl.fi/tutkimushanke/ henkiloston-saatavuuden-ja-alan-vetovoimaisuuden-turvaaminen-iakkaiden-palveluissa-hyva-veto/ (viitattu 12.9.2021).

Valtioneuvosto. Osallistava ja osaava Suomi - sosiaalisesti, taloudellisesti ja ekologisesti kestävä yhteiskunta. Pääministeri Sanna Marinin hallituksen ohjelma 10.12.2019. Valtioneuvoston julkaisuja 2019:23. Internet: https://valtioneuvosto.fi/marinin-hallitus/hallitusohjelma (viitattu 12.9.2021).

Vipunen. Opetushallinnon tilastopalvelu. 2020. Internet: https://vipunen.fi (viitattu 12.9.2021).

XAMK. Terveenä eläkkeelle ja eläkkeellä. KaakkoisSuomen ammattikorkeakoulu, 2021. Internet: https://ejulkaisu.grano.fi/xamk/terveena_elakkeelle\#p=1 (viitattu 19.11.2021). 